\title{
Responsive Pickering Emulsions Stabilized by Frozen Complex Coacervate Core Micelles
}

Julien Es Sayed ${ }^{+*}$, Hugo Brummer ${ }^{\dagger}$, Marc C. A. Stuart $^{\ddagger}$, Nicolas San son $^{\circ}$, Patrick Perrin ${ }^{\circ}$, Marleen Kamperman ${ }^{\dagger}$

†Polymer Science, Zernike Institute for Advanced Materials, University of Groningen, Nijenborgh 4, 9747 AG

Groningen, The Netherlands.

${ }^{\ddagger}$ Groningen Biomolecular Sciences and Biotechnology Institute, University of Groningen Nijenborgh 7, Groningen 9747 AG, The Netherlands

${ }^{\circ}$ Soft Matter Sciences and Engineering, ESPCI, PSL University, Sorbonne Université, CNRS, 10 rue Vauquelin, 75231, Paris Cedex 05, France.

Corresponding authore-mail address: j.s.es.sayed@rug.nl

Supporting information 


\section{Table of Contents}

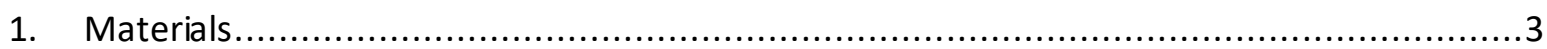

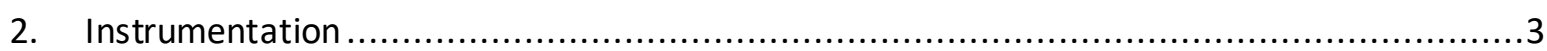

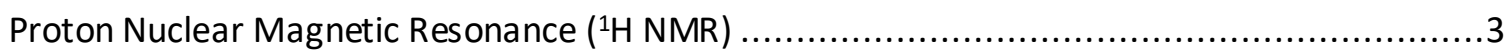

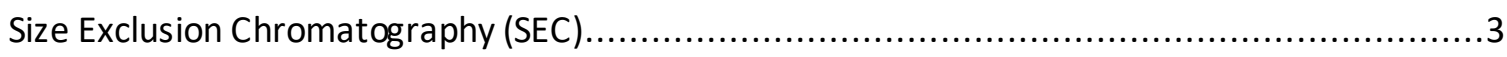

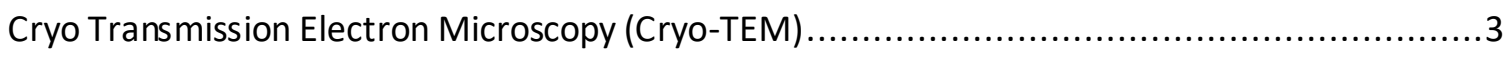

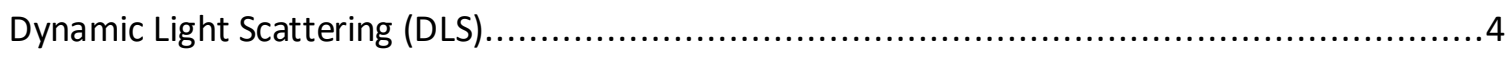

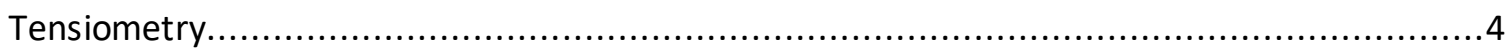

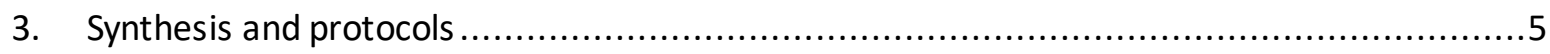

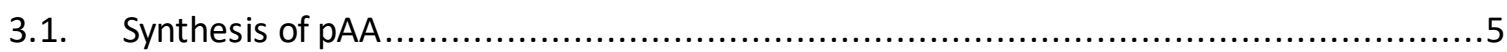

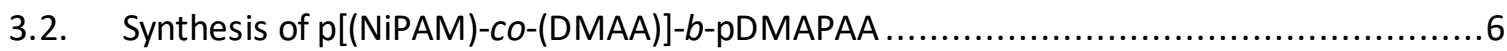

3.3. Synthesized polymer chains composition ......................................................

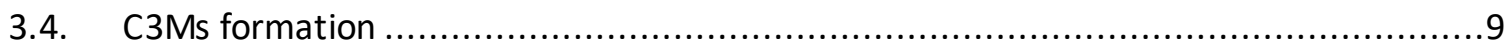

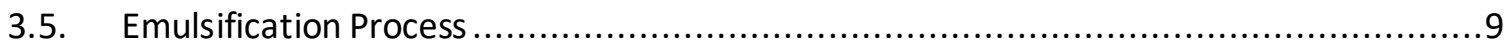

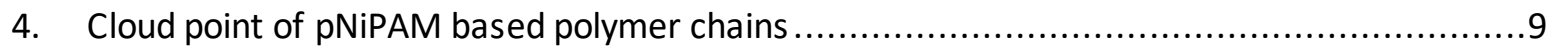

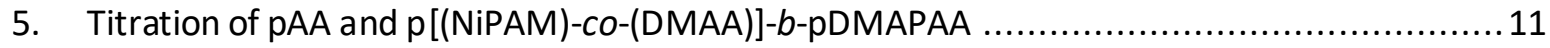

6. Optimum mixing ratio between polyelectrolytes ............................................ 12

7. Particles size depending on the mixing protocol ................................................. 13

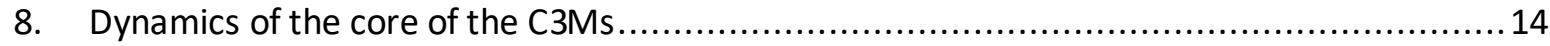

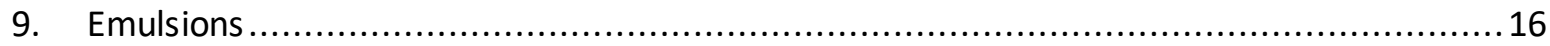

9.1. C3Ms adsorption at dodecane / water interface .......................................... 16

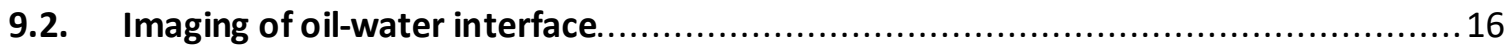

10. Synthesis and characterization of chemically crosslinked core C3Ms (c-C3Ms)..............17

10.1. Protected catechol mon omer synthesis (pCat) ......................................... 17

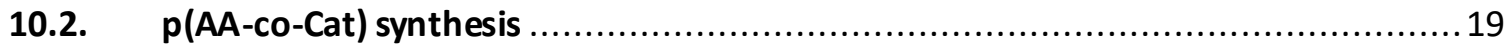

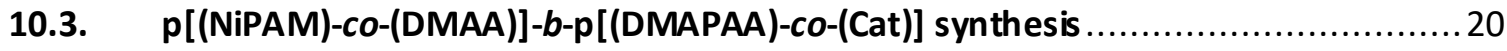

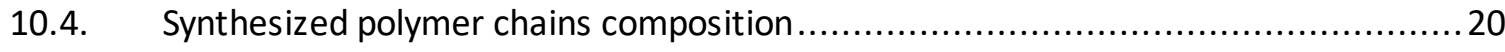

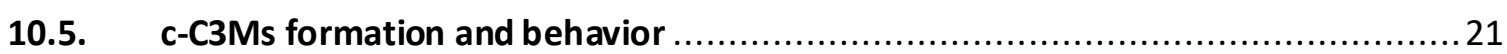

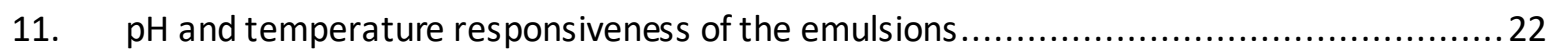

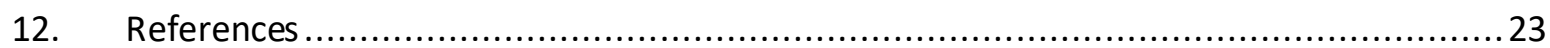




\section{Materials}

Anhydrous tetrahydrofuran (THF), methanol (MeOH), ethyl acetate (AcOEt), diethyl ether $\left(\mathrm{Et}_{2} \mathrm{O}\right), \mathrm{n}$ hexane, aluminum oxide, anhydrous 1,4-dioxane, deuterium oxide, $\mathrm{N}, \mathrm{N}$-dimethylacrylamide (DMAA) monomer 99\%, 2-(dodecylthiocarbonothioylthio)-2-methylpropionic acid (DDMAT), methacryloxyethyl thiocarbamoyl rhodamine B monomer, tert-butyl acrylate (tBA) monomer 98\%, anhydrous $\mathrm{N}, \mathrm{N}$-Dimethylformamide (DMF), $\mathrm{N}$-(3-(dimethylamino)propyl)acrylamide (DMAPAA) monomer, dopamine hydrochloride (DOPA. $\mathrm{HCl}$ ), acryloyl chloride, ethyl acetate (AcOEt), ptoluenesulfonic acid ( $\mathrm{p}$ - $\mathrm{TsOH})$, anhydrous toluene, 2,2-dimethoxypropane, cyclohexane and dodecane were purchased from Sigma Aldrich and used without further purification. $\mathrm{N}$-isopropylacrylamide (NiPAM) monomer and 2,2'-azobis(2-methylpropionitrile) (AIBN) were purchased from Sigma Aldrich and recrystallized once respectively from $n$-hexane and methanol. 1,1,1,3,3,3-Hexafluoro-2-propanol (HFIP) was purchased from Biosolve and used as received. Ultrapure deionized water with a minimum resistivity of $18 \mathrm{M} \Omega . \mathrm{cm}$ (milliQ, Millipore, France) was used for all experiments.

\section{Instrumentation}

Proton Nuclear Magnetic Resonance ( ${ }^{1} \mathrm{H}$ NMR)

${ }^{1} \mathrm{H}$ NMR experiments in $\mathrm{D}_{2} \mathrm{O}$, d6-DMSO and $\mathrm{CDCl}_{3}$ were performed on a Bruker Avance III $\mathrm{HD}$ spectrometer operating at $400 \mathrm{MHz}$, using a standard $5 \mathrm{~mm}$ broadband Smart probe regulated at 25 ${ }^{\circ} \mathrm{C}$. Chemical shift in ppm from tetramethylsilane referenced to the residual isotopomer solvent signal (HOD).

\section{Size Exclusion Chromatography (SEC)}

Size exclusion chromatography (SEC) was performed on a Viscotek GPCmax system equipped with a TDA 302 triple detector array (both Malvern). PolarGel L and PolarGel M columns (Agilent, $8 \mu \mathrm{m} 30$ $\mathrm{cm}$ ) were fitted into the machine and kept at a temperature of $50{ }^{\circ} \mathrm{C} . \mathrm{N}, \mathrm{N}$-dimethylformamide (DMF, 99.9\%, Sigma-Aldrich) with 0.01 M LiBr was used as eluent. Samples were dissolved in the eluent at a concentration of $2 \mathrm{mg} \cdot \mathrm{mL}^{-1}$ and passed through a $0.45 \mu \mathrm{m}$ nylon filter prior injection. Near monodisperse PMMA standards (Polymer Standard Services) were used for the construction of a calibration curve. Data acquisition and calculations were performed using Viscotek OmniSec software version 5.0.

\section{Cryo Transmission Electron Microscopy (Cryo-TEM)}

An aliquot $(3 \mu \mathrm{L})$ of sample was deposited on holey carbon-coated grids (3.5/1 Quantifoil Micro Tools, Jena, Germany) that were previously glow-discharged for $15 \mathrm{~s}$. After the excess liquid was blotted for $4 \mathrm{~s}$, the grids were vitrified in liquid ethane using a Vitrobot (FEI, Eindhoven, The Netherlands) and transferred to a FEI Tecnai T20 electron microscope equipped with a Gatan model 626 cryo-stage operating at $200 \mathrm{keV}$. Micrographs were recorded under low-dose conditions with a slow-scan CCD camera. 


\section{Dynamic Light Scattering (DLS)}

Particles size and polydispersity were measured by photon correlation spectroscopy (PCS) at a detection angle of $90^{\circ}$, using a Zetasizer Ultra Malvern Instrument equipped with a HeNe laser $(\lambda=$ $632.8 \mathrm{~nm}$ ). All analyses were performed with the software supplied by the manufacturer. The resulting data were fitted with a cumulant function and the hydrodynamic diameter was calculated with the Stokes-Einstein equation $d_{H}=\frac{k T}{3 \pi \eta D}$ with $\mathrm{k}$ the Boltzmann constant, $\mathrm{T}$ the temperature $(294 \mathrm{~K}), \mathrm{\eta}$ the solvent viscosity $(0.97 \mathrm{mPa} . \mathrm{s})$ and $D=\frac{\Gamma}{q^{2}}$ the diffusion coefficient, $\Gamma$ being the relaxation rate and $\mathrm{q}$ the wave vector.

\section{Tensiometry}

Oil-water interfacial tensions were measured using the rising drop method (ITC Concept, Tracker). The shape of the drops was fitted to the Laplace equation in order to determine the interfacial tension. Dodecane oil with a purity of $>99 \%$ was used as received, and the C3MS aqueous solutions were prepared using deionized water. The temperature of both the syringe used to form the drop and the water cell was maintained at $21^{\circ} \mathrm{C}$ by circulating water in a double-envelope system. Polymer solutions / dispersions were prepared at $\mathrm{C}=0.5 \mathrm{mg} \cdot \mathrm{mL}^{-1}$. 


\section{Synthesis and protocols}

\subsection{Synthesis of pAA}<smiles>C=CC(=O)OC(C)(C)C</smiles>

tertButyl acrylate (tBA)

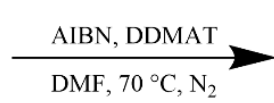<smiles>CCC(C(=O)OC(C)(C)C)C(C)C</smiles>

poly(tertbutyl acrylate) (ptBA)

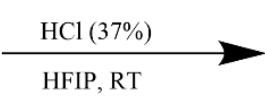
(pAA) poly(acrylic acid)<smiles>C=C(O)C(CC)CC</smiles><smiles>CC(C)(C)O</smiles>

tert butanol

Figure S1. Synthesis scheme of poly(acrylic acid) (pAA).

Tert-butyl acrylate $(4.00 \mathrm{~g}, 31.2 \mathrm{mmol})$, DDMAT $(0.076 \mathrm{~g}, 0.20 \mathrm{mmol})$ and AIBN $(0.006 \mathrm{~g}, 0.04 \mathrm{mmol})$ were dissolved in DMF $(8 \mathrm{~mL})$ in a round bottom flask at room temperature and under $\mathrm{N}_{2}$ flow for 20 min. The reaction medium was then heated to $70{ }^{\circ} \mathrm{C}$ while removing $\mathrm{N}_{2}$ flow and allowed to proceed under continuous stirring. After $5 \mathrm{~h}$, the reaction mixture was exposed to air and the flask was immersed into an ice-cold bath in order to stop the polymerization. The monomer conversion was measured to be $95 \%$ by means of ${ }^{1} \mathrm{H}$ NMR. The synthesized polymers were purified from unreacted monomers by precipitation in an ice cold mixture of water and $\mathrm{MeOH}(1: 1 \mathrm{v} / \mathrm{v})$. After drying overnight under vacuum $\left(31 \mathrm{mbar}, 45^{\circ} \mathrm{C}\right)$ the polymer chains were dissolved in HFIP $(200 \mathrm{~mL})$ in a large round bottom flask at room temperature. $2.2 \mathrm{~mL}$ of concentrated hydrochloric acid (37\%) was added and the deprotection reaction was allowed to proceed under continuous stirring. After $18 \mathrm{~h}$, volatiles were removed using a combination of $\mathrm{N}_{2}$ bubbling, rotary evaporation and drying under vacuum ( $31 \mathrm{mbar}$, $45^{\circ} \mathrm{C}$ ). The polymer chains were dissolved in water and freeze-dried to obtain a white fluffy polymer with a yield of $87 \%$. 

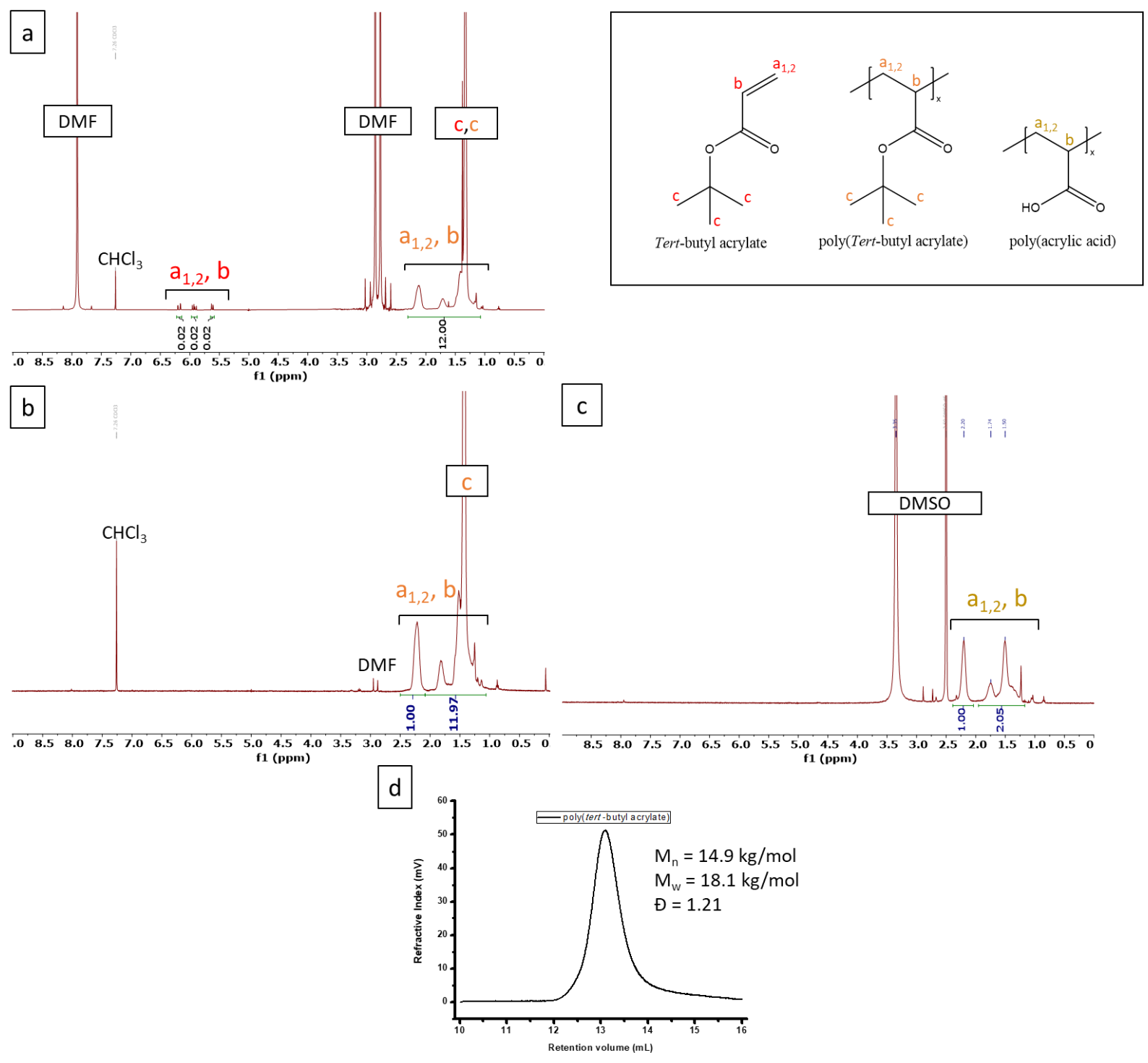

Figure S2. ${ }^{1} \mathrm{H}$ NMR of (a) reaction medium after five hours $\left(\mathrm{CDCl}_{3}\right)$, (b) purified poly(tert-butyl acrylate), ptBA, in $\mathrm{CDCl}_{3}$, (c) purified poly(acrylic acid), pAA, in $\mathrm{D}_{2} \mathrm{O}$ and (d) SEC chromatogram of ptBA in $0.01 \mathrm{M}$ $\mathrm{LiBr}$ in DMF.

\subsection{Synthesis of $\mathrm{p}[(\mathrm{NiPAM})-c o-(\mathrm{DMAA})]-b-\mathrm{pDMAPAA}$}

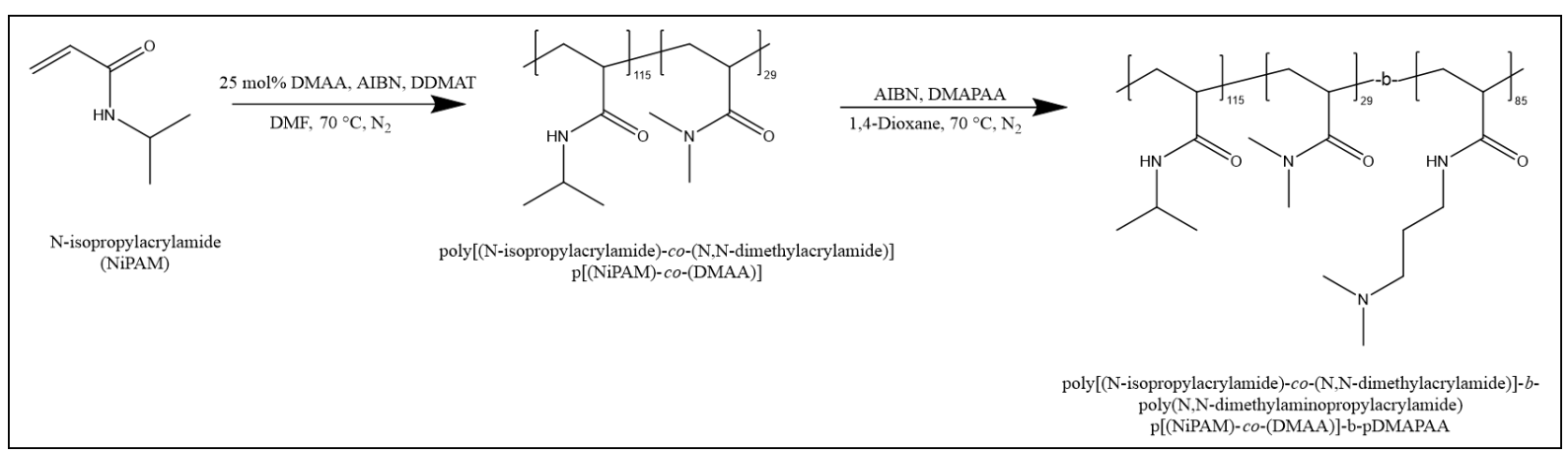

Figure S3. Synthesis scheme of p[(NiPAM)-co-(DMAA)]-b-pDMAPAA polycation diblock. 
The first block, p[(NiPAM)-co-(DMAA)], was synthesized by thermally initiated RAFT polymerization. In a typical synthesis, NiPAM $(3.00 \mathrm{~g}, 26.5 \mathrm{mmol})$, DMAA $(0.66 \mathrm{~g}, 6.60 \mathrm{mmol})$, DDMAT $(0.080 \mathrm{~g}, 0.22$ $\mathrm{mmol}$ ) and AIBN $(0.007 \mathrm{~g}, 0.05 \mathrm{mmol})$ were dissolved in DMF $(6 \mathrm{~mL})$ in a round bottom flask at room temperature and under $\mathrm{N}_{2}$ flow for $20 \mathrm{~min}$. The reaction medium was then heated to $70{ }^{\circ} \mathrm{C}$ while removing $\mathrm{N}_{2}$ flow and allowed to proceed under continuous stirring. After $4 \mathrm{~h}$, the reaction mixture was exposed to air and the flask was immersed into an ice-cold bath in order to stop the polymerization. The monomer conversion was measured to $97 \%$ by mean of ${ }^{1} \mathrm{H}$ NMR. The synthesized polymers were purified from un-reacted monomers by precipitation in ice cold diethyl ether. The product was dried overnight under vacuum $\left(31 \mathrm{mbar}, 45^{\circ} \mathrm{C}\right)$ to obtain a white polymer powder with a yield of $90 \%$.

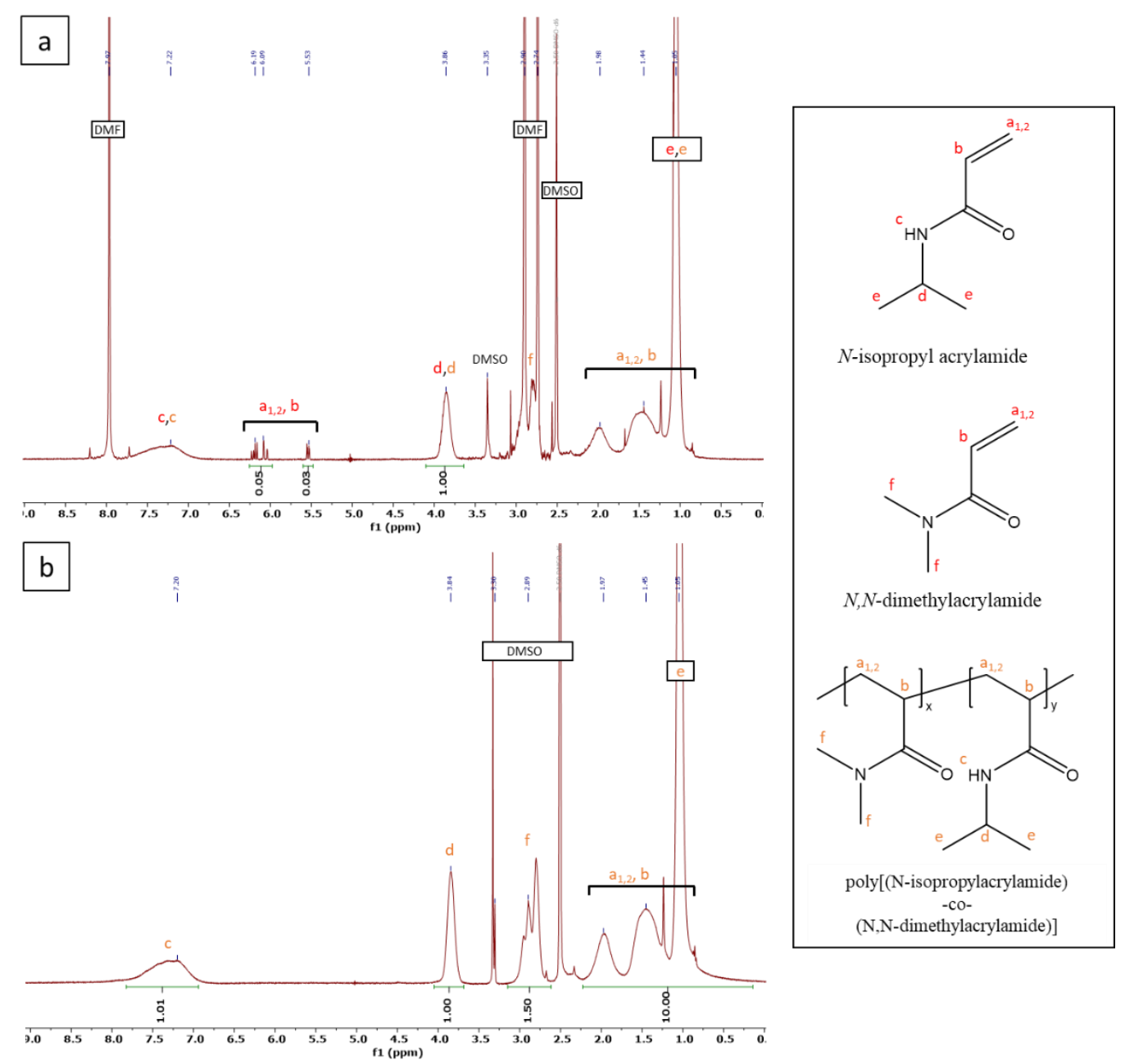

Figure S4. ${ }^{1} \mathrm{H}$ NMR of $(\mathbf{a})$ reaction medium after 4 hours (DMSO- $\mathrm{d}_{6}$ ) and (b) purified $\mathrm{p}[(\mathrm{NiPAM})$-co(DMAA)] (DMSO-d $)_{6}$.

The second block, pDMAPAA, was attached to the p[(NiPAM)-co-(DMAA)] by thermally triggered macro RAFT polymerization. In a typical synthesis, macro-RAFT agent p[(NiPAM)-co-(DMAA)] (1.0 g, $0.06 \mathrm{mmol})$, DMAPAA $(0.990 \mathrm{~g}, 6.40 \mathrm{mmol}), \operatorname{AIBN}(0.002 \mathrm{~g}, 0.01 \mathrm{mmol})$ and Rhodamine B monomer were dissolved in anhydrous 1,4-dioxane $(5 \mathrm{~mL})$ in a round bottom flask at room temperature and under $\mathrm{N}_{2}$ flow for $20 \mathrm{~min}$. The reaction medium was then heated to $70{ }^{\circ} \mathrm{C}$ while removing $\mathrm{N}_{2}$ flow and allowed to proceed under continuous stirring. After $24 \mathrm{~h}$, the reaction mixture was exposed to air and the flask was immersed into an ice-cold bath in order to stop the polymerization. The monomer conversion was measured to be $84 \%$ by means of ${ }^{1} \mathrm{H}$ NMR. The synthesized polymers were purified from un-reacted monomers by precipitation in an ice cold mixture of $n$-hexane and THF (4:1 v/v). The 
product was dried overnight under vacuum $\left(31 \mathrm{mbar}, 45^{\circ} \mathrm{C}\right)$ to obtain a pink polymer powder with a yield of $64 \%$.
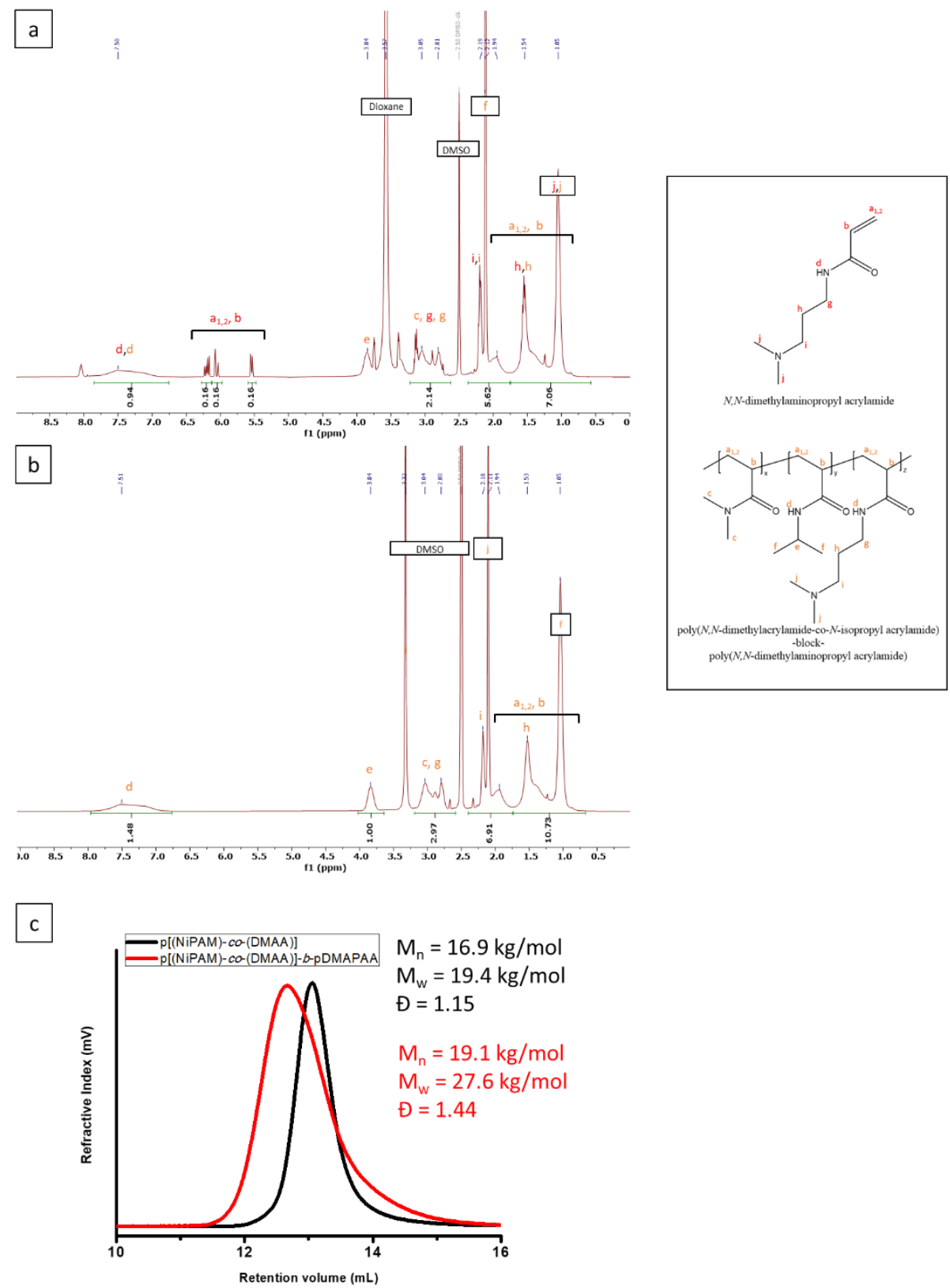

Figure S5. ${ }^{1} \mathrm{H}$ NMR of $(\mathrm{a})$ reaction medium after 24 hours (DMSO- $\left.\mathrm{d}_{6}\right)$, (b) purified p[(NiPAM)-co(DMAA)]-b-pDMAPAA (DMSO-d ${ }_{6}$ ) and (c) SEC chromatogram of p[(NiPAM)-co-(DMAA)] first block and p[(NiPAM)-co-(DMAA)]-b-pDMAPAA diblock in $0.01 \mathrm{M} \mathrm{LiBr}$ in DMF. 
3.3. Synthesized polymer chains composition

Monomer conversion and final product composition were determined by ${ }^{1} \mathrm{H}$ NMR and enabled us to determine the size of the polymer chains:

\begin{tabular}{|c|c|c|}
\hline & Monomer & $\mathrm{DP}_{\mathrm{n}}$ \\
\hline $\operatorname{pAA}(-)$ & $\mathrm{AAc}$ & 147 \\
\hline \multirow{2}{*}{$\mathrm{p}[($ NiPAM)-co-(DMAA)]- $b$-pDMAPAA $(+)$} & NiPAM & 115 \\
\cline { 2 - 3 } & DMAA & 29 \\
\cline { 2 - 3 } & DMAPAA & 85 \\
\hline
\end{tabular}

\subsection{C3Ms formation}

pAA and p[(NiPAM)-co-(DMAA)]- $b$-pDMAPAA were separately dissolved in a $1 \mathrm{M} \mathrm{NaCl}$ solution of PBS buffer adjusted at $\mathrm{pH} 7\left(10^{-2} \mathrm{M}\right)$. The polyelectrolytes were combined in a 1:1 ratio of chargeable monomer units (total monomer concentration of $0.12 \mathrm{~mol}^{\mathrm{L}} \mathrm{L}^{-1}$ ). The homogeneous mixture was further dialysed ( $3.5 \mathrm{kDa}$ cut-off regenerated cellulose membrane) for 4 hours against $0.5 \mathrm{M} \mathrm{NaCl}$ PBS buffer $(\mathrm{pH} 7)$. Then, the medium was dialysed against $10^{-2} \mathrm{M} \mathrm{PBS}$ buffer at $\mathrm{pH} 7$ and finally against deionized water. The dialysis process was continued until the conductivity of the medium inside the bag matched the one of deionized water $(10 \mu \mathrm{S} / \mathrm{cm})$. The $\mathrm{pH}$ was continuously controlled to be 7 during the whole dialysis process. Finally, the resulting C3Ms were freeze-dried and stored as powder for further use.

\subsection{Emulsification Process}

$0.4 \mathrm{~mL}$ of dodecane (+ $1 \mathrm{v} / \mathrm{v} \%$ of hexadecane or iso-octane) were emulsified with $1 \mathrm{~mL}$ of C3Ms dispersion in $0 \mathrm{M} \mathrm{NaCl}$ water $\left(\mathrm{C}_{\mathrm{C} 3 \mathrm{Ms}}=0.2-10 \mathrm{mg} / \mathrm{mL}\right.$ ) by ultra-sonication (Sonics Vibra-Cell VCX-130, $130 \mathrm{~W}, 20 \mathrm{kHz}$ ) for 1 minute in interval of 5 seconds at $60 \%$ amplitude to prevent overheating of the samples. During sonication, the samples were cooled in an ice bath to reduce coalescence.

\section{Cloud point of pNiPAM based polymer chains}
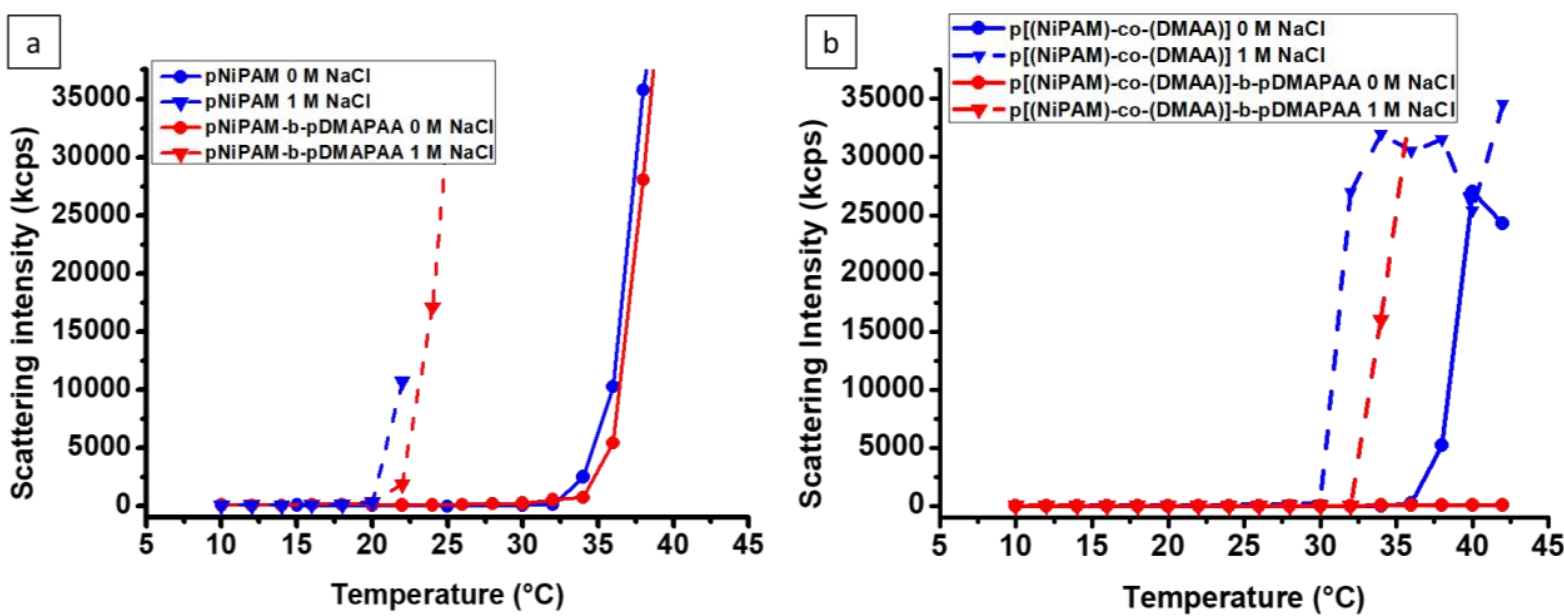

Figure S6. Evolution of the scattering intensity of (a) $p$ (NiPAM) and $p$ (NiPAM)- $b$-pDMAPAA, (b) $\mathrm{p}[(\mathrm{NiPAM})-c o-(\mathrm{DMAA})]$ and $\mathrm{p}[(\mathrm{NiPAM})-c o-(\mathrm{DMAA})]-b-\mathrm{pDMAPAA}$ solutions in water with temperature at $0 \mathrm{M}$ and $1 \mathrm{M} \mathrm{NaCl}$ at a polymer concentration of $1 \mathrm{mg} / \mathrm{mL}$ and $\mathrm{pH} 7$. 
The cloud point of the pNiPAM homopolymer was determined at 34 and $22^{\circ} \mathrm{C}$ at 0 and $1 \mathrm{M} \mathrm{NaCl}$, respectively. The copolymerization of NiPAM with $20 \mathrm{~mol} \%$ of DMAA increased the cloud point temperature of the $\mathrm{p}[(\mathrm{NiPAM}-\mathrm{Co}-\mathrm{DMAA})]$ to 38 and $32^{\circ} \mathrm{C}$ for 0 and $1 \mathrm{M} \mathrm{NaCl}$, respectively, ensuring full solubility of the corona at the working temperature of $21^{\circ} \mathrm{C}$ for the whole range of $\mathrm{NaCl}$ concentrations investigated. 


\section{Titration of pAAand p[(NiPAM)-co-(DMAA)]-b-pDMAPAA}

In order to determine the degree of ionization as a function of $\mathrm{pH}, \mathrm{pH}$ titrations were performed on pAA and $\mathrm{p}[(\mathrm{NiPAM})-c o-(\mathrm{DMAA})]-b$-pDMAPAA solutions to determine the $\mathrm{pK}$. and the $\mathrm{pK}{ }_{+} . \mathrm{pH}$ titrations were carried out on $5 \mathrm{mg} / \mathrm{mL}$ solutions at $[\mathrm{NaCl}]=0.1 \mathrm{M}$, starting from a fully protonated form for $\mathrm{pAA}$, and from a fully deprotonated form for $\mathrm{p}[(\mathrm{NiPAM})$-co-(DMAA)]- $b$-pDMAPAA. Sodium hydroxide $(\mathrm{NaOH}) 0.1 \mathrm{M}$ and hydrochloric acid $(\mathrm{HCl}) 0.1 \mathrm{M}$ solutions were used to modify the $\mathrm{pH}$. The effective $\mathrm{pK}$. and $\mathrm{pK}_{+}$were taken as the $\mathrm{pH}$ halfway of the equivalence point and could be used to calculate the degree of ionization as a function of $\mathrm{pH}$ (Figure S7), according to the following equations: ${ }^{1}$

$$
\begin{aligned}
& \alpha_{-}=\frac{10^{p H-p K_{-}}}{1+10^{p H-p K_{-}}} \\
& \alpha_{+}=\frac{10^{p K_{+}-p H}}{1+10^{p K_{+}-p H}}
\end{aligned}
$$
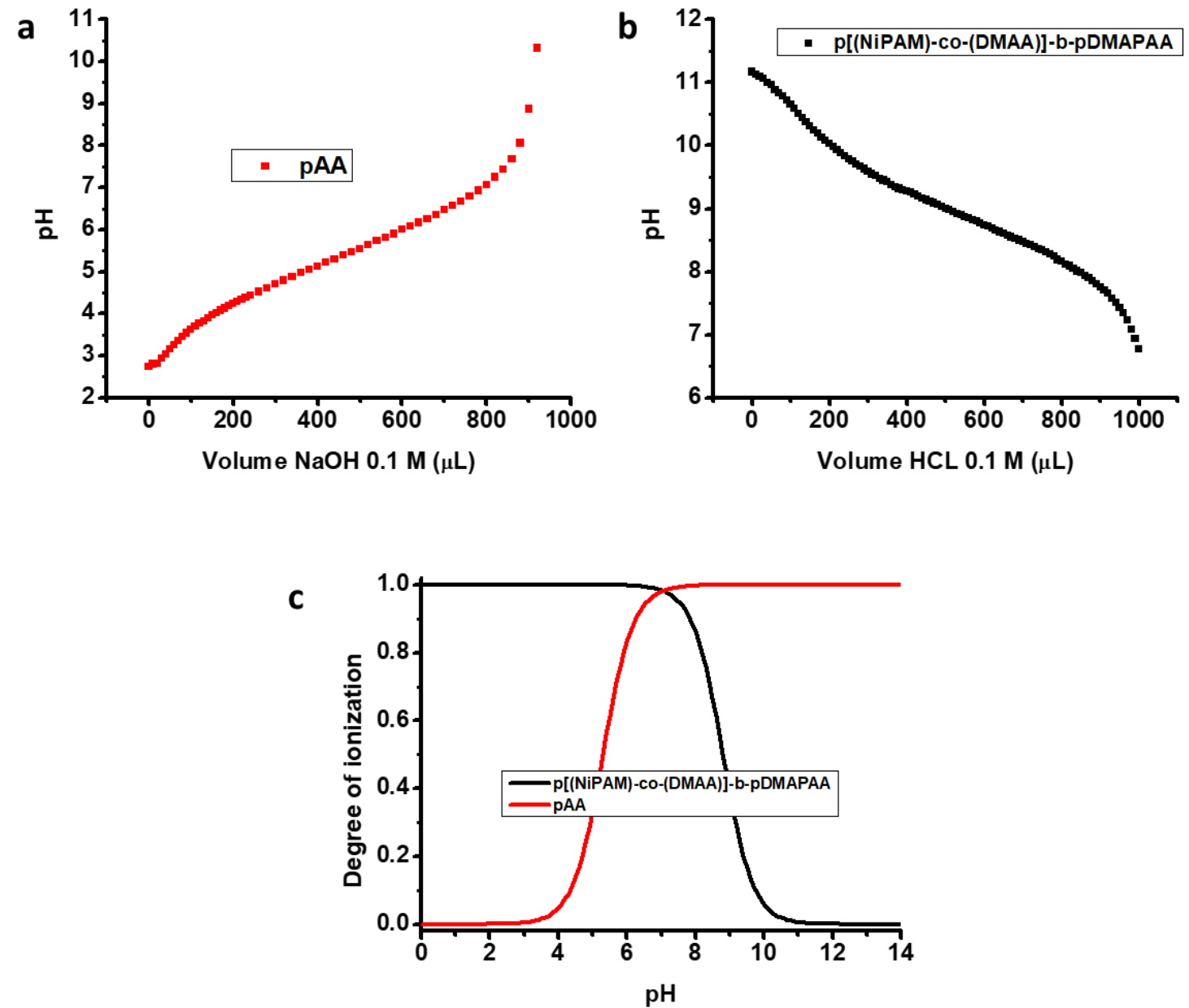

Figure S7. Titration curves of of (a) pAA and (b) p[(NiPAM)-co-(DMAA)]-b-pDMAPAA. (c) Degree of ionisation of the two polyelectrolytes as a function of $\mathrm{pH}$. 


\section{Optimum mixing ratio between polyelectrolytes}
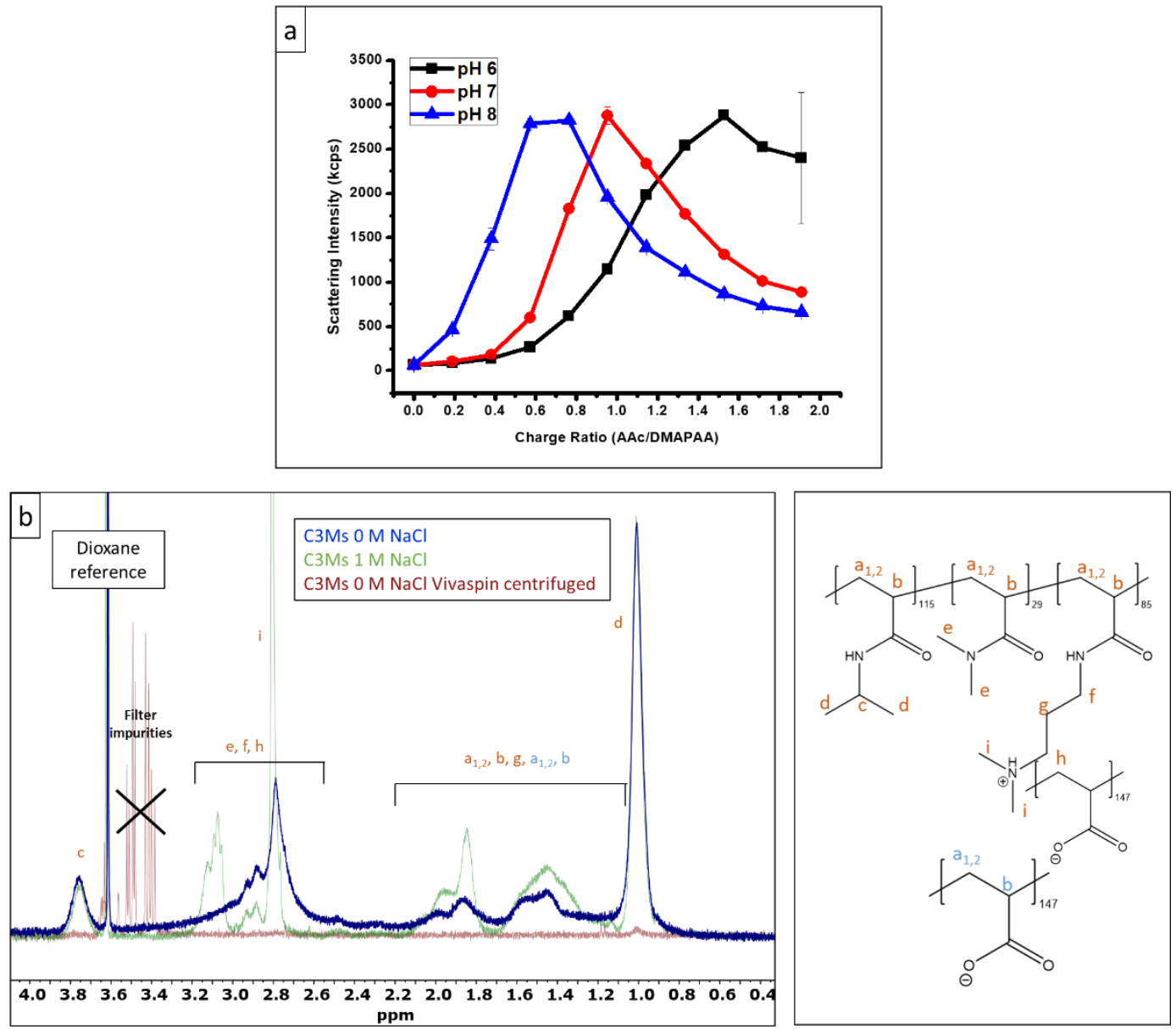

Figure S8. (a) Evolution of the scattering intensity of p[(NiPAM)-co-(DMAA)]-b-pDMAPAA and pAA mixture in water with the mixing ratio AAC/DMAPAA at $\mathrm{pH} 6,7$ and 8 . (b) Overlayed ${ }^{1} \mathrm{H}$ NMR spectra of C3Ms dispersed in $0 \mathrm{M}$ (blue), $1 \mathrm{M} \mathrm{NaCl}$ (green) and of the subnatant of $0 \mathrm{M} \mathrm{NaClC3M}$ dispersion centrifuged through a $30 \mathrm{kDa}$ MWCO membrane (red). 1,4-Dioxane is used as internal reference. The absence of polymer related peak in the sub-natant shows that all the chains are embedded in the C3Ms. 


\section{Particles size depending on the mixing protocol}
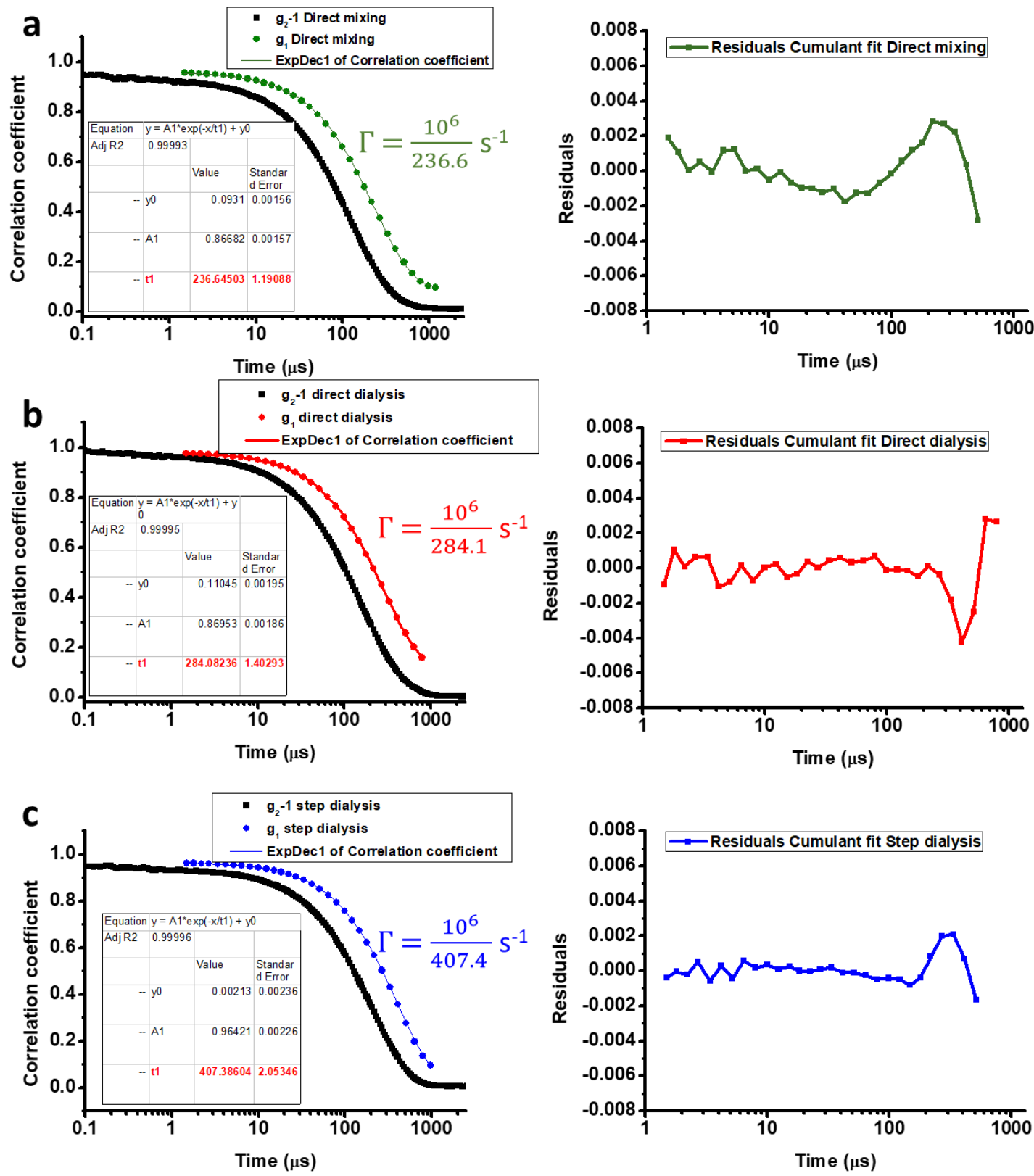

Figure S9. Measured intensity autocorrelation function $g_{2}-1(t)$, calculated electric field correlation function $\mathrm{g}_{1}(\mathrm{t})$, cumulant fit and residuals of $\mathrm{g}_{1}(\mathrm{t})$ for the C3Ms samples obtained by $(\mathrm{a})$ direct mixing, (b) direct dialysis and (c) step dialysis. 
8. Dynamics of the core of the C3Ms

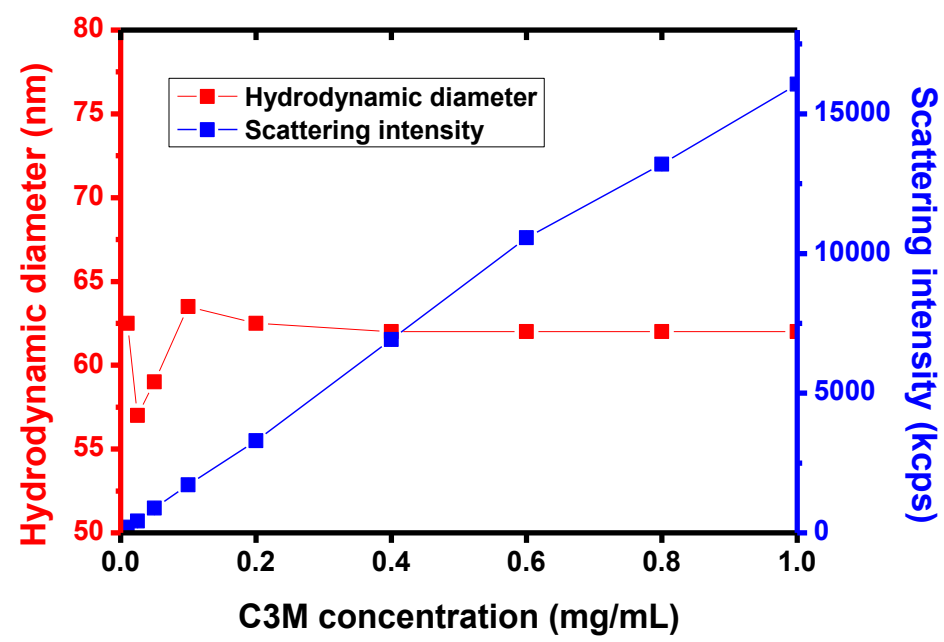

Figure S10. Evolution of scattered light intensity and mean hydrodynamic diameter $\left(d_{h}\right)$ versus polymer concentration in the C3Ms at a ratio $(-):(+)=1: 1$ in water $0 \mathrm{M} \mathrm{NaCl}$.

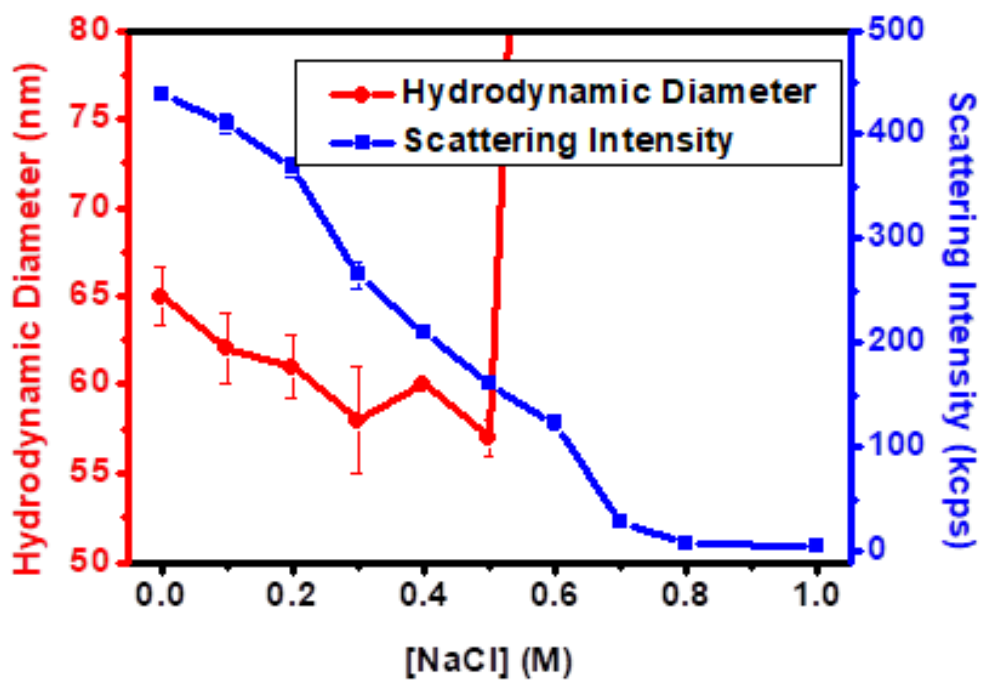

Figure S11. Average hydrodynamic diameter and light scattering intensity of a C3Ms dispersion in $\mathrm{D}_{2} \mathrm{O}$ as a function of the $\mathrm{NaCl}$ concentration from 0 to $1 \mathrm{M}$ (both at $C_{\mathrm{C} 3 \mathrm{M}}=0.5 \mathrm{mg} \cdot \mathrm{mL}^{-1}$ ). 

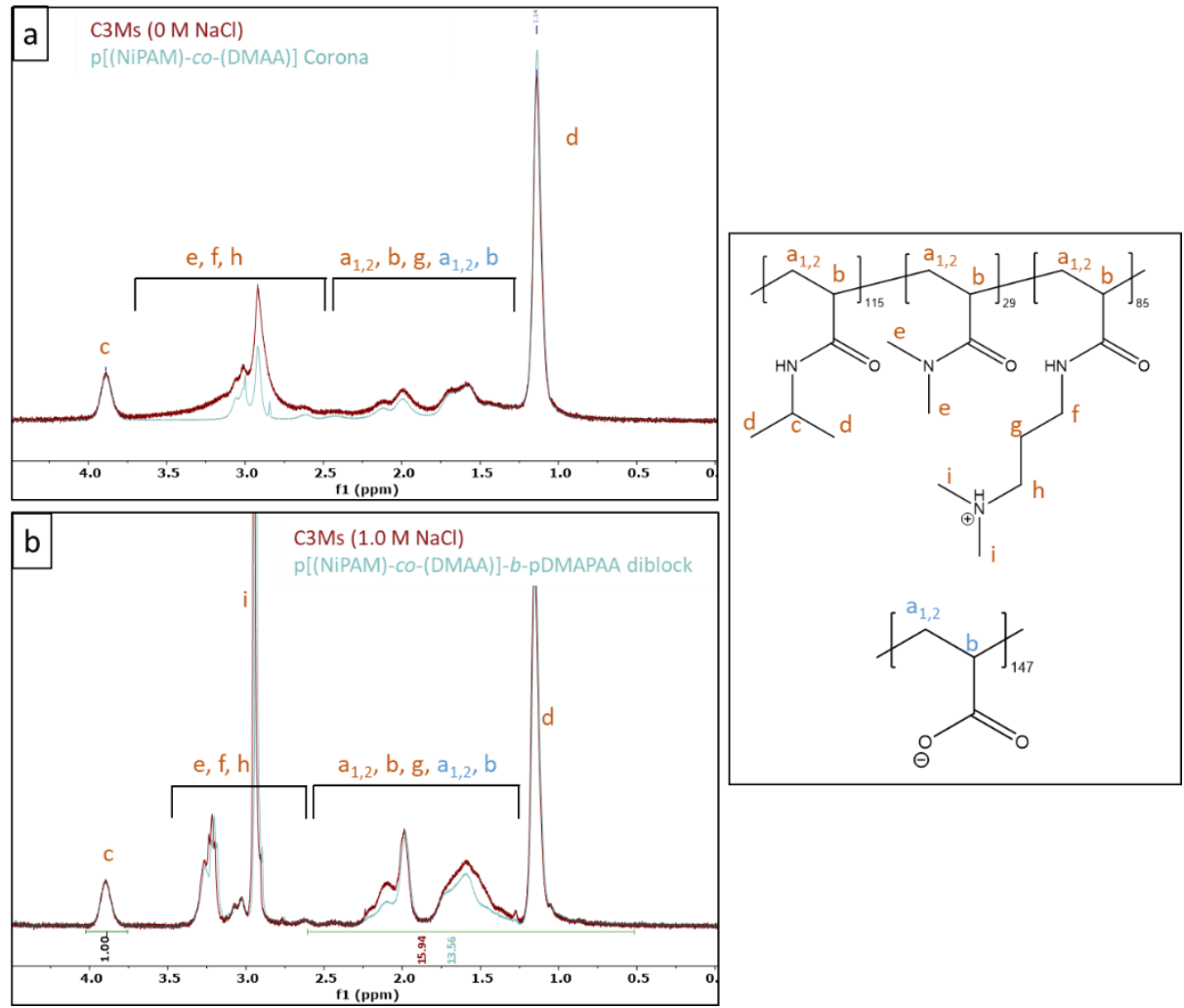

Figure S12. Zoomed in ${ }^{1} \mathrm{H}$ NMR spectra in the region [0 - $\left.4.5 \mathrm{ppm}\right]$ of (a) the C3Ms and p[(NiPAM)-co(DMAA)] neutral block at $0 \mathrm{M} \mathrm{NaCl}$ in $\mathrm{D}_{2} \mathrm{O}$ and $(\mathbf{b})$ the $\mathrm{C} 3 \mathrm{Ms}$ and $\mathrm{p}$ [(NiPAM)-co-(DMAA)]-b-pDMAPAA diblock at $1 \mathrm{M} \mathrm{NaCl}$ in $\mathrm{D}_{2} \mathrm{O}$.

The integral values between 0.5 and $2.5 \mathrm{ppm}$ (containing protons $a_{1}, a_{2}, b, d, g$ ) were calculated to be 15.9 for the $\mathrm{C} 3 \mathrm{Ms}$ at $1.0 \mathrm{M} \mathrm{NaCl}$, and 13.6 for the $\mathrm{p}$ [(NiPAM)-co-(DMAA)]- $b$-pDMAPAA copolymer. The difference between these integral values, a value of 2.3 .

By calculating the ratio between the monomers in the diblock copolymer, and taking into account that we mixed the oppositely charge polymers with a ratio of $1: 1$ between DMAPAA and AAc, the expected integral value of $A A c$ can be calculated to be 2.2 as shown in the Table below. The obtained integral values matchup between free polymer chains and C3Ms at $1 \mathrm{M} \mathrm{NaCl}$.

According to the integral values determined for the diblock p[(NiPAM)-co-(DMAA)]-b-pDMAPAA, the following ratios between monomers is determined as follows:

\begin{tabular}{|l|l|l|l|l|}
\hline & NiPAM & DMAA & DMAPAA & AAc \\
\hline Molar ratio & 1 & 0.25 & 0.74 & 0.74 \\
\hline
\end{tabular}

In the chemical shift range from 0.5 to $2.5 \mathrm{ppm}$ we expect the following number of protons and the theoretical integral value compared to the methine peak of the NiPAM units chosen as internal reference :

\begin{tabular}{|l|l|l|}
\hline Monomer & No.protons & Theoretical integral value \\
\hline NiPAM & 9 & $\left(9^{*} 1\right)=9$ \\
\hline DMAA & 3 & $\left(3^{*} 0.25\right)=0.75$ \\
\hline DMAPAA & 5 & $\left(5^{*} 0.74\right)=3.70$ \\
\hline AAC & 3 & $\left(3^{*} 0.74\right)=2.22$ \\
\hline
\end{tabular}




\section{Emulsions}

\subsection{C3Ms adsorption at dodecane / water interface}

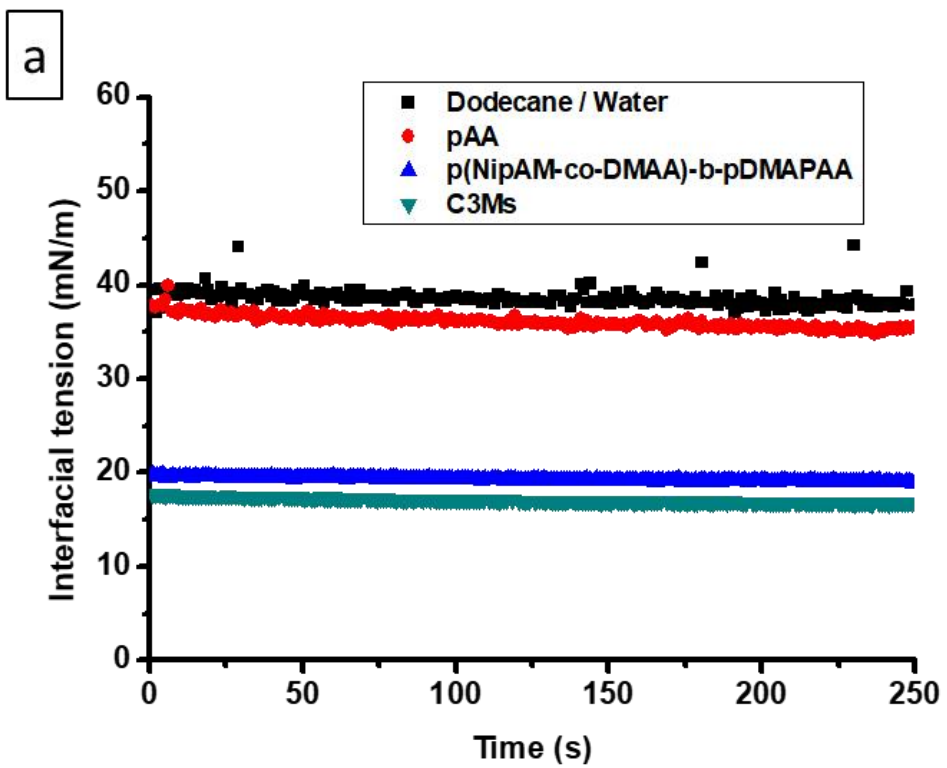

b

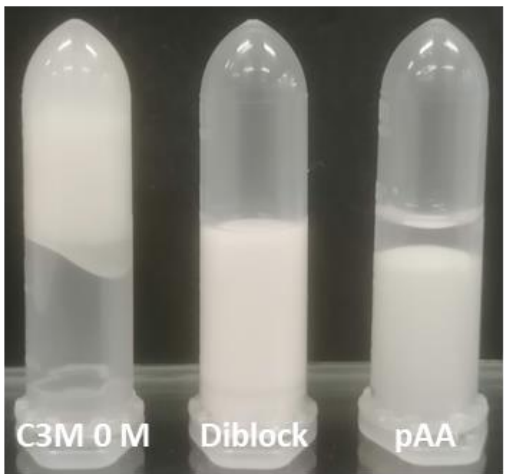

Figure S13. (a) Evolution of dodecane / water interfacial tension (black) in presence of pAA (red),

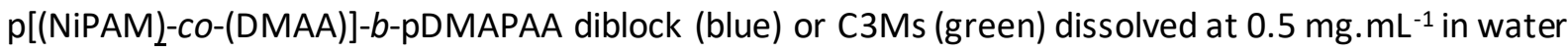
at $\mathrm{pH}$ 7. (b) Flocculated aspect of dodecane-in-water emulsions in presence of C3Ms, p[(NiPAM)-co(DMAA)]-b-pDMAPAA diblock or pAA at a polymer concentration of $0.5 \mathrm{mg} \cdot \mathrm{mL}^{-1}$. The highly flocculated state of dodecane drops in the presence of $\mathrm{C} 3 \mathrm{Ms}$ prevents the system to flow in the inverted container.

\subsection{Imaging of oil-water interface}
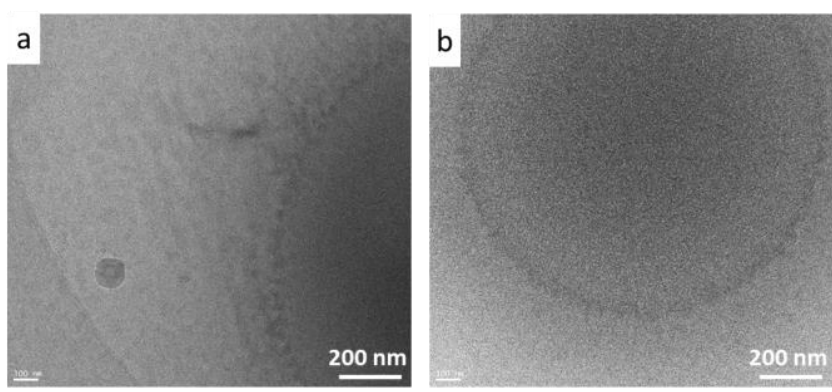

Figure S14. (a), (b) Cryo-TEM images of dodecane (+ $10 \mathrm{v} / \mathrm{v} \%$ isooctane) drops in water stabilized by C3Ms adsorbed (scale bar is $200 \mathrm{~nm}$ ). 


\section{Synthesis and characterization of chemically crosslinked core C3Ms (c-C3Ms) 10.1. Protected catechol monomer synthesis ( $\mathrm{pCat}$ )}

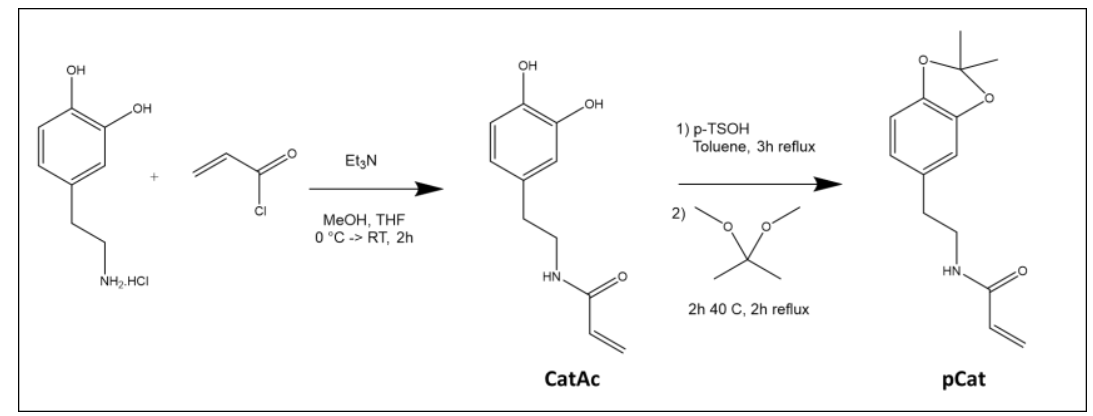

Figure S15. Synthesis scheme of CatAc and pCat monomers.

The following synthesis protocols were inspired from the work of Patil et al. ${ }^{2}$

DOPA. $\mathrm{HCl}(3.99 \mathrm{~g}, 21.0 \mathrm{mmol})$ and $\mathrm{Et}_{3} \mathrm{~N}(3.24 \mathrm{ml}, 23.2 \mathrm{mmol})$ were dissolved in $\mathrm{MeOH}(70 \mathrm{ml})$ and cooled on an ice bath. THF solution ( $3 \mathrm{ml})$ of acryloyl chloride $(2.05 \mathrm{ml}, 25.2 \mathrm{mmol})$ and $\mathrm{MeOH}$ solution $(5 \mathrm{ml})$ of triethylamine $(4.23 \mathrm{ml}, 30.3 \mathrm{mmol})$ were added dropwise to the DOPA. HCl solution. After adding the reagent, the reaction mixture was stirred at room temperature for $2 \mathrm{~h}$. Solvent was removed under vacuo. The residue was dissolved in ethyl acetate (AcOEt) and washed with $1 \mathrm{M}$ hydrochloric acid $(\mathrm{HCl})$ and brine. The organic layer was dried over sodium sulfate, then filtrated, and concentrated by evaporation. The product was recrystallized from AcOEt, giving CatAc $(2.40 \mathrm{~g}, 11.6$ $\mathrm{mmol}$ ) with $55 \%$ yield as a white solid. ${ }^{1} \mathrm{H}$ NMR $\left(400 \mathrm{MHz}, \mathrm{DMSO}-\mathrm{d}_{6}\right) \delta(\mathrm{ppm}) 8.68\left(\mathrm{br}, 2 \mathrm{H}, \mathrm{Ph}-(\mathrm{OH})_{2}\right)$, 8.11 (br, $1 \mathrm{H},-\mathrm{N} \underline{\mathrm{H}}-\mathrm{)}), 6.62$ (d, $J=8.0 \mathrm{~Hz}, 1 \mathrm{H},-\mathrm{Ph}-), 6.58$ (d, $J=2.0,1 \mathrm{H},-\mathrm{Ph}-$ ), 6.45 (dd, $J=8.0$ and $J=2.0$ $\mathrm{Hz}, 1 \mathrm{H},-\mathrm{Ph}-$ ), 6.20 (dd, $J=10.0$ and $J=17.1 \mathrm{~Hz}, 1 \mathrm{H},-\mathrm{CH}_{2}=\mathrm{C}-\underline{\mathrm{H}}-$ ), 6.08 (dd, $J=17.1$ and $J=2.3 \mathrm{~Hz}, 1 \mathrm{H}$, $\mathrm{C}_{2}=\mathrm{CH}-$ ), 5.56 (dd, $J=10.0$ and $J=2.3 \mathrm{~Hz}, 1 \mathrm{H},-\mathrm{CH}_{2}=\mathrm{CH}-$ ), 3.27 (app q, $\left.2 \mathrm{H}, \mathrm{Ph}-\mathrm{CH}_{2}-\mathrm{C}_{2}-{ }_{2}\right), 2.55$ (t, $J=7.5$ $\left.\mathrm{Hz}, 2 \mathrm{H},-\mathrm{Ph}-\underline{\mathrm{C}}_{2}-\right) .{ }^{13} \mathrm{CNMR}(100 \mathrm{MHz}, \mathrm{DMSO}-\mathrm{d} 6, \delta(\mathrm{ppm})): 164.5(1 \mathrm{C},-\mathrm{NH}-\underline{\mathrm{C}}=\mathrm{O}), 145.0(1 \mathrm{C}, \mathrm{Ph}-\mathrm{O}(\underline{\mathrm{C}}))$, $143.5(1 \mathrm{C}, \mathrm{Ph}-\mathrm{OH}(\underline{\mathrm{C}})), 131.9\left(1 \mathrm{C},-\underline{\mathrm{CH}}=\mathrm{CH}_{2}\right), 130.2\left(1 \mathrm{C}, \mathrm{Ph}-\underline{\mathrm{CH}}_{2}-\right), 124.8\left(1 \mathrm{C},-\mathrm{CH}=\mathrm{CH}_{2}\right), 119.2(1 \mathrm{C}, \mathrm{Ph})$, $116.0(1 \mathrm{C}, \mathrm{Ph}), 115.5(1 \mathrm{C}, \mathrm{Ph}), 40.6\left(1 \mathrm{C},-\mathrm{CH}_{2}-\mathrm{NH}-\right)$, $34.6\left(1 \mathrm{C},-\mathrm{CH}_{2}-\mathrm{CH}_{2}-\right)$. UV-Vis $\left(\mathrm{H}_{2} \mathrm{O}\right) \lambda \max (\varepsilon)=280$ $\mathrm{nm}\left(2591 \mathrm{~L} \cdot \mathrm{mol}^{-1} \cdot \mathrm{cm}^{-1}\right)$.

$1.35 \mathrm{~g}(6.5 \mathrm{mmol})$ of CatAc and $0.62 \mathrm{~g}(0.36 \mathrm{mmol})$ of $\mathrm{p}-\mathrm{TsOH}$ as a catalyst were dissolved in anhydrous toluene $(75 \mathrm{~mL})$ under nitrogen atmosphere. A Dean-Stark apparatus was attached and the solution was refluxed for $3 \mathrm{~h}$. The flask was then cooled to $0{ }^{\circ} \mathrm{C}$, and $7.5 \mathrm{~mL}(61.3 \mathrm{mmol})$ of 2,2dimethoxypropane was added. A soxhlet extractor, whose thimble was filled with $10.0 \mathrm{~g}$ of $\mathrm{CaCl}_{2}$ was attached and the flask was warmed to $40^{\circ} \mathrm{C}$ for $2 \mathrm{~h}$. The solution was then vigorously stirred under reflux for another $2 \mathrm{~h}$. The mixture was washed with water, brine and dried over MgSO4. The solvent was removed in vacuum to yield a crude orange paste, which was further purified by flash silica gel column chromatography eluting with a cyclohexane-ethyl acetate (5:5) mixture giving pCat (1.24 g, $5.0 \mathrm{mmol})$ with $74 \%$ yield as a white solid. ${ }^{1} \mathrm{H}$ NMR $(400 \mathrm{MHz}$, DMSO-d 6 ) $\delta(\mathrm{ppm}) 8.13(\mathrm{br}, 1 \mathrm{H},-\mathrm{N} \underline{\mathrm{H}}-)$, $6.56-6.74(\mathrm{~m}, 3 \mathrm{H}, \mathrm{Ph}), 6.20$ (dd, $J=10.0$ and $J=17.1 \mathrm{~Hz}, 1 \mathrm{H},-\mathrm{CH}_{2}=\mathrm{C} \underline{\mathrm{H}}-$ ), 6.08 (dd, $J=17.1$ and $J=2.3$ $\mathrm{Hz}, 1 \mathrm{H},-\mathrm{C}_{2}=\mathrm{CH}-$ ), 5.56 (dd, $J=10.0$ and $J=2.3 \mathrm{~Hz}, 1 \mathrm{H},-\mathrm{C}_{2}=\mathrm{CH}$ ), 3.31 (app q, $2 \mathrm{H}, \mathrm{Ph}_{-} \mathrm{CH}_{2}-\mathrm{C}_{2}-{ }_{2}$ ), 2.63 $\left(\mathrm{t}, J=7.5 \mathrm{~Hz}, 2 \mathrm{H},-\mathrm{Ph}-\mathrm{C}_{2}-\right), 1.61\left(\mathrm{~s}, 6 \mathrm{H},\left(\mathrm{CH}_{3}\right)_{2}-\mathrm{C}-\right) .{ }^{13} \mathrm{C} \mathrm{NMR}(100 \mathrm{MHz}$, DMSO-d6, $\delta(\mathrm{ppm})): 164.5$ (1C, $-\mathrm{NH}-\mathrm{C}=\mathrm{O}), 146.9\left(1 \mathrm{C}, \mathrm{Ph}-\mathrm{O}\left(\mathrm{C}(\mathrm{Me})_{2}\right)\right), 145.2\left(1 \mathrm{C}, \mathrm{Ph}-\mathrm{O}\left(\mathrm{C}(\mathrm{Me})_{2}\right)\right), 132.6\left(1 \mathrm{C},-\mathrm{CH}=\mathrm{CH}_{2}\right), 131.8$ (1C, $\mathrm{Ph}-$ $\left.\mathrm{CH}_{2}-\right), 124.9(1 \mathrm{C},-\mathrm{CH}=\mathrm{CH} 2), 121.0(1 \mathrm{C}, \mathrm{Ph}), 117.6\left(-\mathrm{C}\left(\mathrm{CH}_{3}\right)_{2}\right), 108.7(1 \mathrm{C}, \mathrm{Ph}), 107.8(1 \mathrm{C}, \mathrm{Ph}), 40.4(1 \mathrm{C},-$ $\left.\mathrm{CH}_{2}-\mathrm{NH}-\right), 34.8\left(1 \mathrm{C},-\mathrm{CH}_{2}-\mathrm{CH}_{2}-\right), 25.5\left(1 \mathrm{C},\left(\mathrm{CH}_{3}\right)_{2}-\mathrm{C}-\right)$. 


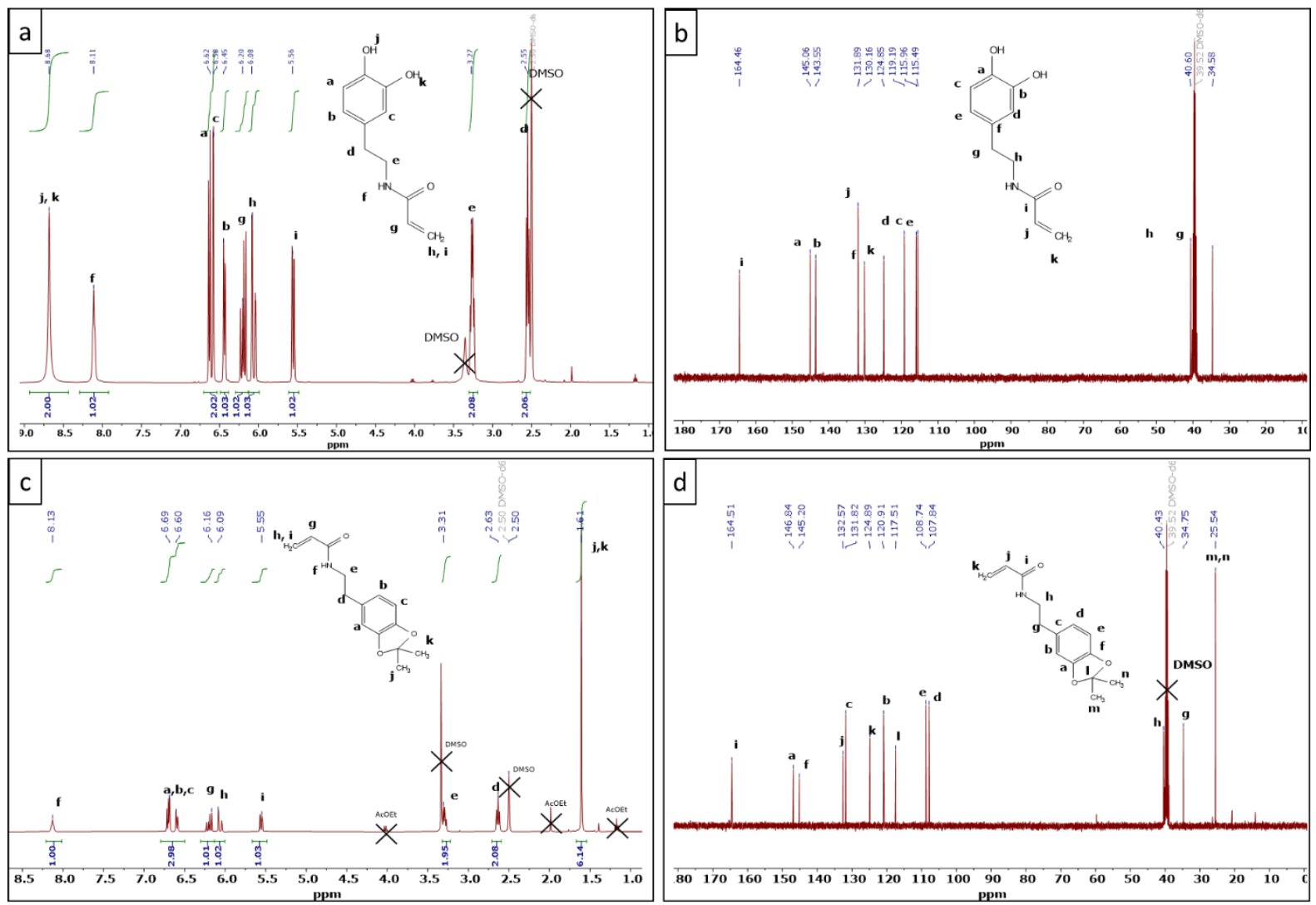

Figure S16. ${ }^{1} \mathrm{H}$ and ${ }^{13} \mathrm{C}$ NMR spectra of (a),(b) CatAc and (c),(d) pCat in DMSO-d6. 


\section{2. $\quad p(A A-c o-C a t)$ synthesis}

The protocol for $\mathrm{p}[(\mathrm{AA})-\mathrm{co}-(\mathrm{Cat})]$ synthesis is identical to the one of pAA. The only difference is that 5 mol\% vs tert-butyl acrylate of pCat monomer $(0.40 \mathrm{~g}, 1.6 \mathrm{mmol})$ was added in the medium.

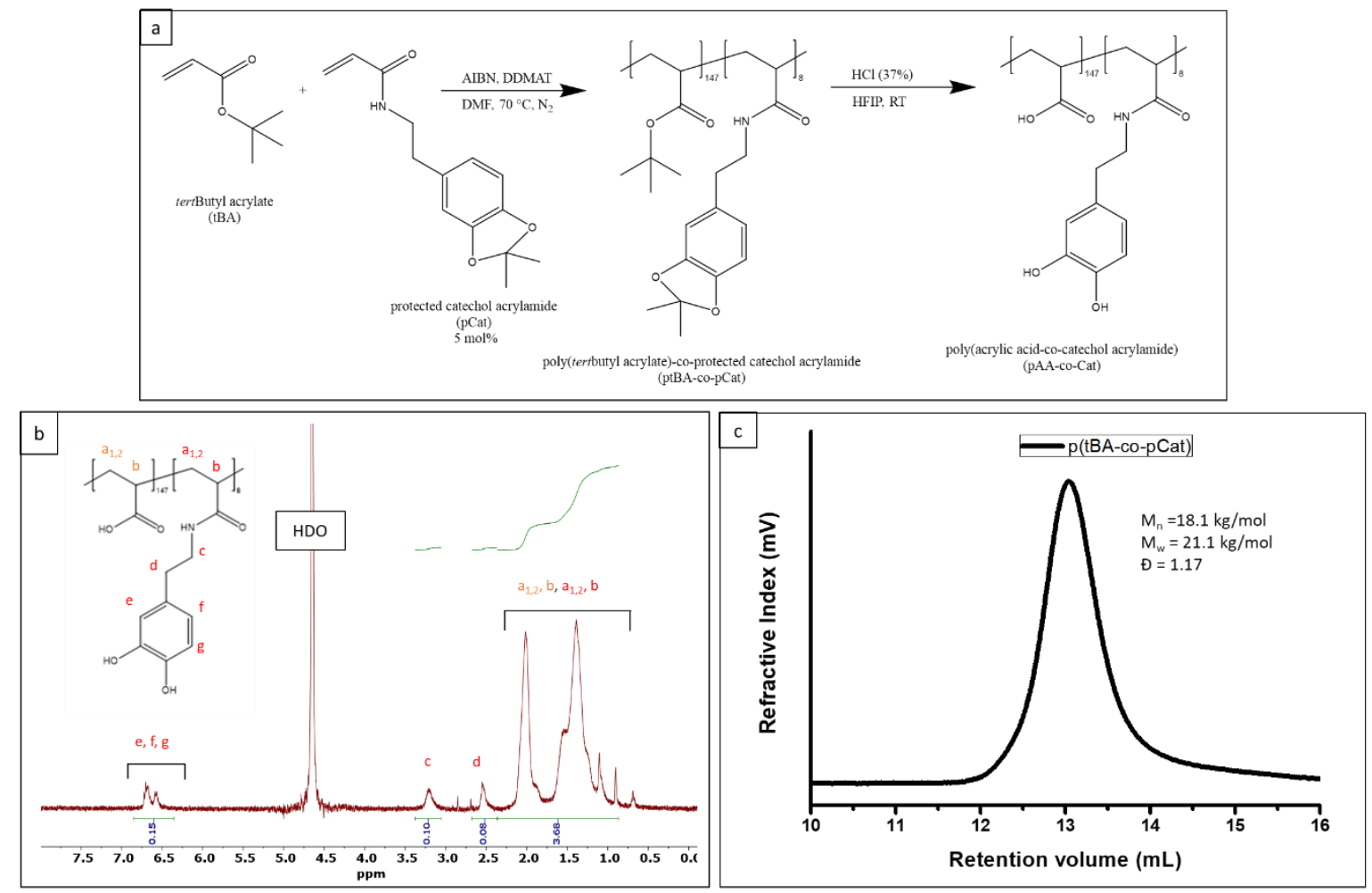

Figure S17. (a) Synthesis scheme and (b) $1 \mathrm{H}$ NMR (in $\mathrm{D}_{2} \mathrm{O}$ ) of $\mathrm{p}[(\mathrm{AA})-\mathrm{co}-($ Cat)] polyanion and (c) SEC chromatogram of $\mathrm{p}[(\mathrm{tBA})-\mathrm{co}-(\mathrm{pCat})]$ in $0.01 \mathrm{M} \mathrm{LiBr}$ in DMF. 


\section{3. $\quad \mathrm{p}[($ NiPAM)-co-(DMAA)]-b-p[(DMAPAA)-co-(Cat)] synthesis}

The protocol for p[(NiPAM)-co-(DMAA)]-b-p[(DMAPAA)-co-(Cat)] synthesis is similar to the one of $\mathrm{p}[($ NiPAM)-co-(DMAA)]- $b$-pDMAPAA. The only differences are that 5 mol\% vs DMAPAA of pCat monomer $(0.08 \mathrm{~g}, 0.32 \mathrm{mmol})$ was added in the medium to synthesize the second block. The deprotection of the catechol moieties in the p[(NiPAM)-co-(DMAA)]-b-p[(DMAPAA)-co-(pCat)] was performed in a $2 \mathrm{M}$ aqueous solution of $\mathrm{HCl}$ water for $12 \mathrm{~h}$ at RT. The solution was then dialyzed until the $\mathrm{pH}$ reaches a value of 6 and then freeze-dried.

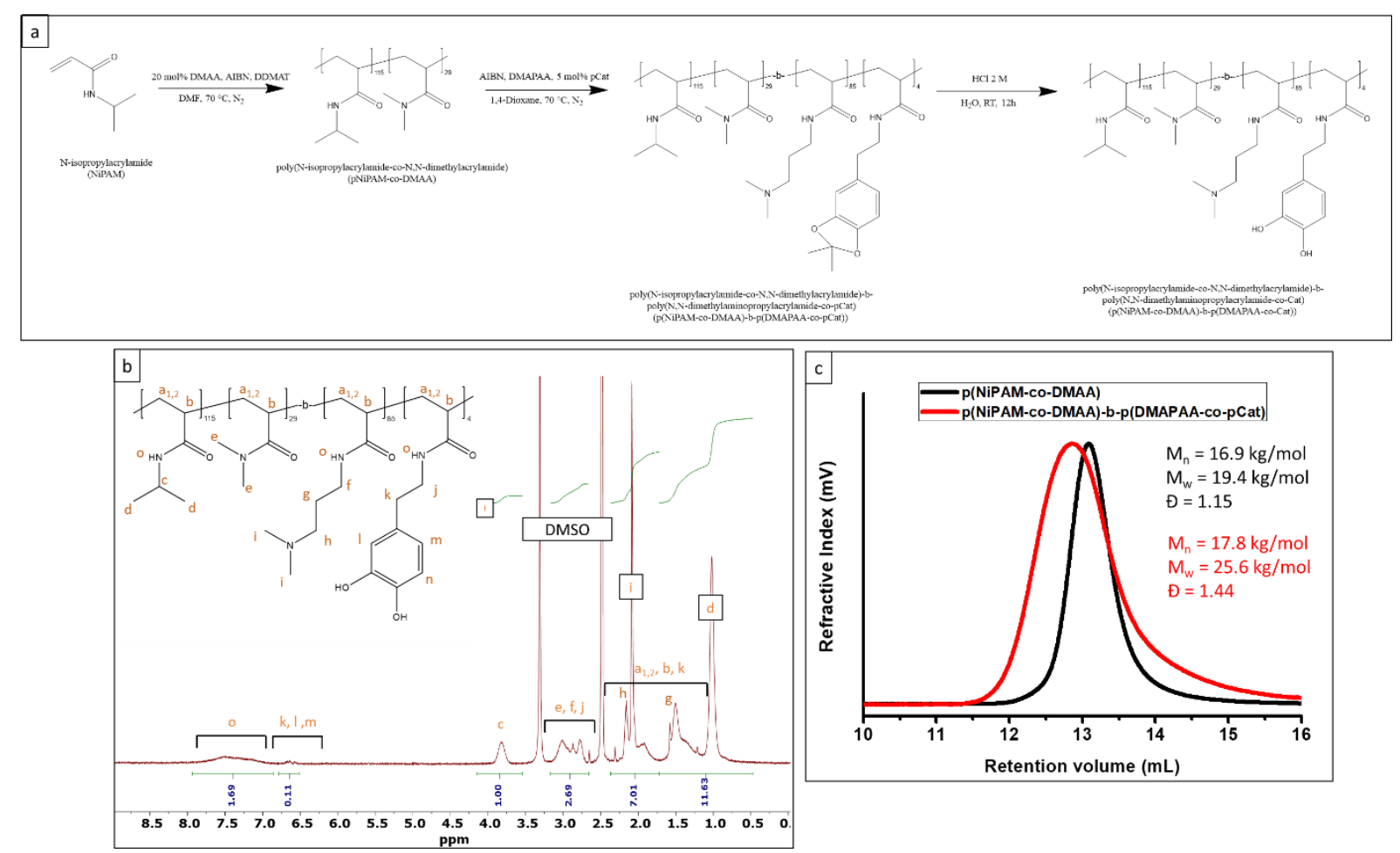

Figure S18. (a) Synthesis scheme and (b) $1 \mathrm{H}$ NMR (in DMSO- $\mathrm{d}_{6}$ ) of $\mathrm{p}[(\mathrm{NiPAM})-\mathrm{co}-(\mathrm{DMAA})]-b-$ p[(DMAPAA)-co-(Cat)] polycation. (c) SEC chromatogram of $p[($ NiPAM)-co-(DMAA)] first block and $\mathrm{p}[($ NiPAM)-co-(DMAA)]-b-p[(DMAPAA)-co-(pCat)] diblock in $0.01 \mathrm{M} \mathrm{LiBr}$ in DMF.

\subsection{Synthesized polymer chains composition}

Monomer conversion and final product composition were determined by ${ }^{1} \mathrm{H}$ NMR and enabled us to determine the size of the polymer chains :

\begin{tabular}{|c|c|c|}
\hline & Monomer & $\mathrm{DP}_{\mathrm{n}}$ \\
\hline $\mathrm{P}[(\mathrm{AA})-c o-($ Cat $)](-)$ & $\mathrm{AAc}$ & 145 \\
\cline { 2 - 3 } & $\mathrm{pCat}$ & 8 \\
\hline \multirow{3}{*}{$\mathrm{p}[$ (NiPAM)-co-(DMAA)]-b-p[(DMAPAA)-co-(Cat)] $(+)$} & $\mathrm{NiPAM}$ & 115 \\
\cline { 2 - 3 } & $\mathrm{DMAA}$ & 29 \\
\cline { 2 - 3 } & DMAPAA & 89 \\
\cline { 2 - 3 } & pCat & 4 \\
\hline
\end{tabular}




\section{5. c-C3Ms formation and behavior}

$\mathrm{p}[(\mathrm{AA})-\mathrm{co}-(\mathrm{Cat})]$ and $\mathrm{p}[(\mathrm{NiPAM})-c o-(\mathrm{DMAA})]-b-\mathrm{p}[(\mathrm{DMAPAA})-c o-(\mathrm{Cat})]$ were separately dissolved in a 1 $\mathrm{M} \mathrm{NaCl}$ solution of PBS buffer adjusted at $\mathrm{pH} 7\left(10^{-2} \mathrm{M}\right)$. The polyelectrolytes were combined in a 1:1 ratio of chargeable monomer units (total chargeable monomer concentration of $0.12 \mathrm{~mol}^{\mathrm{L}} \mathrm{L}^{-1}$ ). The homogeneous mixture was further dialysed ( $3.5 \mathrm{kDa}$ cut-off regenerated cellulose membrane) for 4 hours against $0.5 \mathrm{M} \mathrm{NaCl}$ PBS buffer $(\mathrm{pH} 7)$. Sodium metaperiodate $\left(\mathrm{NaIO}_{4}\right)$ was then added to the dispersion (inside the dialysis bag) at a ratio 1:2 compared to the catechol units to induce the oxidationmediated catechol dimerization and form covalent crosslinks between associated chains. ${ }^{3}$ Then, the medium was dialysed against $10^{-2} \mathrm{M} \mathrm{PBS}$ buffer at $\mathrm{pH} 7$ and finally against deionized water. The dialysis process was continued until the conductivity of the medium inside the bag matched the one of deionized water $(10 \mu \mathrm{S} / \mathrm{cm})$. The $\mathrm{pH}$ was continuously controlled to be 7 during the whole dialysis process. Finally, the resulting C3Ms were freeze-dried and stored as powder for further use.

Combination of DLS measurements and cryo-TEM imaging showed that the formed C-C3Ms did not disassemble even at $1 \mathrm{M} \mathrm{NaCl}$ thanks to the covalent crosslinking of the complex coacervate core (Figure S15).

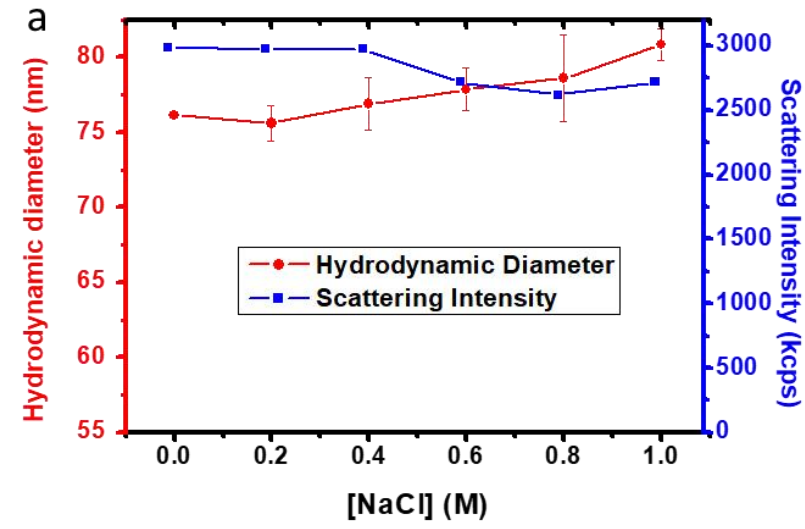

C

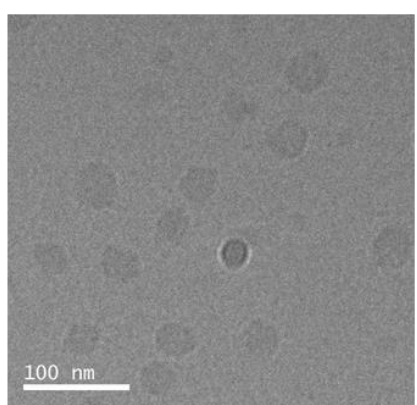

b

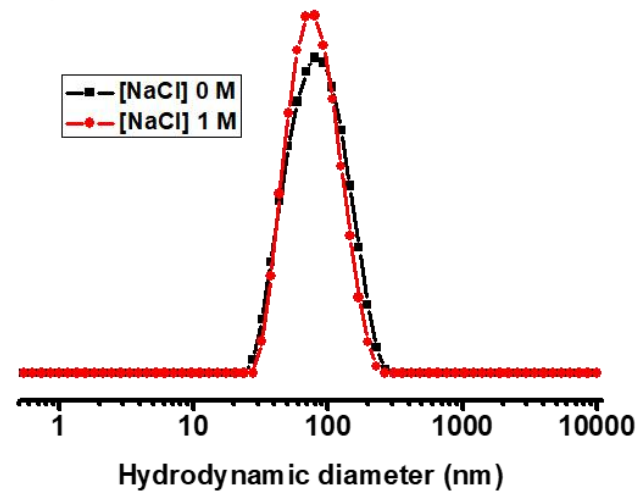

d

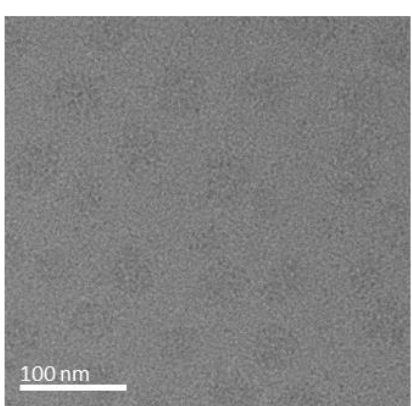

Figure S19. (a) Average hydrodynamic diameter and light-scattering intensity of a c-C3Ms dispersion in $\mathrm{H}_{2} \mathrm{O}$ in function of the $\mathrm{NaCl}$ concentration from 0 to $1 \mathrm{M}$. (b) Size distribution of the c-C3Ms at $0 \mathrm{M}$ and $1 \mathrm{M} \mathrm{NaCl}$ in $\mathrm{H}_{2} \mathrm{O}$ measured by DLS. Cryo-TEM images of c-C3Ms at (c) $0 \mathrm{M} \mathrm{NaCl}$ and (d) $1 \mathrm{M} \mathrm{NaCl}$ in $\mathrm{H}_{2} \mathrm{O}$. Scale bars are $100 \mathrm{~nm}$. 


\section{1. $\mathrm{pH}$ and temperature responsiveness of the emulsions}

a

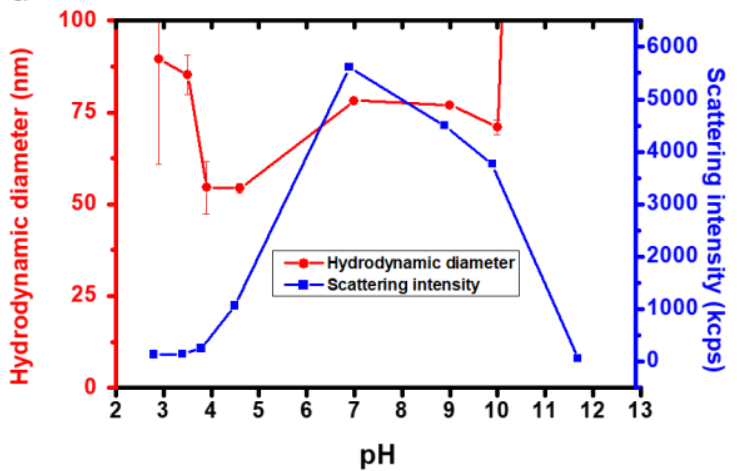

b

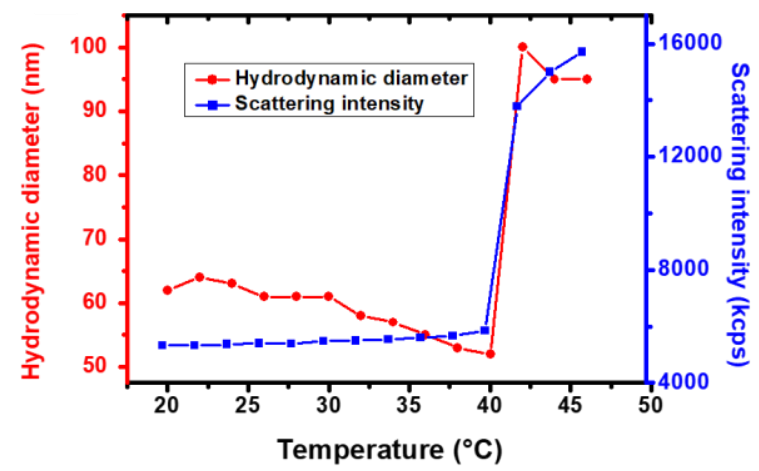

Figure S20. Average hydrodynamic diameter and light-scattering intensity of a C3Ms dispersion in $\mathrm{H}_{2} \mathrm{O}$ at $\mathrm{OM} \mathrm{NaCl}$ in function of (a) the $\mathrm{pH}$ and (b) the temperature. 


\section{References}

1. Spruijt, E.; Westphal, A. H.; Borst, J. W.; Cohen Stuart, M. A.; van der Gucht, J., Binodal Compositions of Polyelectrolyte Complexes. Macromolecules 2010, 43 (15), 6476-6484.

2. Patil, N.; Falentin-Daudré, C.; Jérôme, C.; Detrembleur, C., Mussel-inspired protein-repelling ambivalent block copolymers: controlled synthesis and characterization. Polymer Chemistry 2015, 6 (15), 2919-2933.

3. Yang, J.; Stuart, M. A. C.; Kamperman, M., Jack of all trades: versatile catechol crosslinking mechanisms. Chemical Society Reviews 2014, 43 (24), 8271-8298. 